Izabella WĘGIELNIK

Studentka kierunku „turystyka i rekreacja” WNG UŁ

Bogdan WŁODARCZYK

Uniwersytet Łódzki

\title{
BADANIA WPEYWU INWESTYCJI TURYSTYCZNYCH W UNIEJOWIE NA JAKOŚĆ ŻYCIA MIESZKAŃCÓW
}

\section{Wstęp}

Uniejów jako miasto historyczne oraz prężnie rozwijający się ośrodek turystyczny i uzdrowiskowy jest przedmiotem wielu opracowań naukowych zarówno o charakterze monograficznym (SZYMCZAK, red. 1995), jak i specjalistycznym (m.in. WILUŚ 1997, SAPIŃSKA-ŚLIWA 2012, SMĘTKIEWICZ, SMĘTKIEWICZ 2013, PRUGAR 2014). To także jeden z nielicznych ośrodków miejskich i turystycznych, któremu poświęcono czasopismo naukowe „Biuletyn Uniejowski” (MARSZAŁ, red. 2012, 2013, KOBOJEK, red. 2014, 2015), podejmujące tematy z życia miasta i okolic. Uniejów jest również poligonem badawczym studentów przygotowujących swoje prace licencjackie i magisterskie realizowane na Wydziale Nauk Geograficznych UŁ.

Mając na uwadze ponadprzeciętne walory turystyczne miejscowości oraz dynamicznie powstające i rozwijające się w oparciu o posiadane zasoby inwestycje, w niniejszej pracy postanowiono poddać analizie wybrane aspekty jakości życia mieszkańców Uniejowa oraz wpływu na nie realizowanych w mieście inwestycji turystycznych. Celem przeprowadzonych badan było poznanie opinii uniejowian dotyczącej oddziaływania inwestycji tury- 


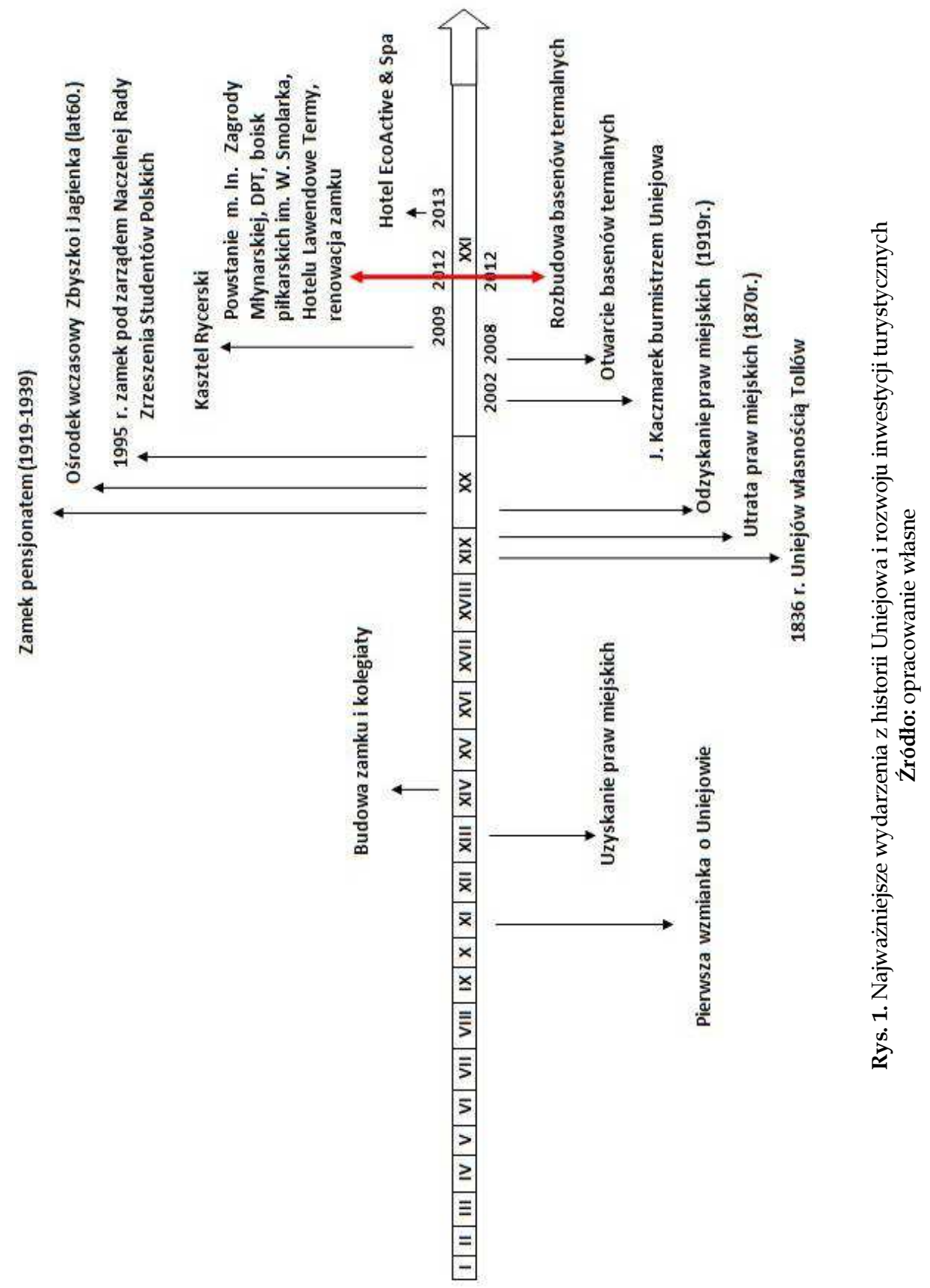


stycznych na ich życie. Przedmiot analiz stanowiła jakość życia psychicznego, funkcjonalnego, somatycznego, środowiskowego i siedliskowego $\mathrm{w}$ kontekście realizowanych inwestycji turystycznych oraz ocena ich wpływu na atrakcyjność turystyczną miasta.

Uniejów, położony w centralnej części Polski nad rzeką Wartą, znajduje się w odległości około $51 \mathrm{~km}$ na południowy zachód od geometrycznego środka Polski, wyznaczonego w miejscowości Piątek (powiat łęczycki), oraz blisko $200 \mathrm{~km}$ na południowy zachód od geometrycznego środka Europy. Leży w południowo-zachodniej części gminy o tej samej nazwie i jest siedzibą funkcjonującego tam Urzędu Miasta i Gminy Uniejów. Zawiera się w granicach powiatu poddębickiego i województwa łódzkiego. Granice gminy Uniejów są zarazem północno-zachodnimi granicami powiatu poddębickiego z tureckim, jak również województwa łódzkiego z wielkopolskim.

Miasto z racji swojej lokalizacji ma dogodną dostępność komunikacyjną, a na terenie gminy Uniejów występuje dobrze rozwinięta sieć dróg zapewniająca szybkie połączenia z sąsiednimi gminami. Miejscowość znajduje się w odległości około $55 \mathrm{~km}$ na północny zachód od Łodzi, $170 \mathrm{~km}$ na południowy wschód od Warszawy oraz $153 \mathrm{~km}$ na południowy wschód od Poznania. Uniejów położony jest przy drodze krajowej nr 72 Łódź-Konin oraz przy drogach wojewódzkich nr 476 Koło-Łask i nr 469 Uniejów-Ozorków. Przez teren gminy (w części północnej) przebiega także autostrada A2. Zjazd i wjazd na nią znajduje się w węźle Dąbie w odległości około $10 \mathrm{~km}$ na północ od Uniejowa.

Nazwa miasta jest nazwą dzierżawczą od imienia Uniej (PRUGAR 2014). Najdawniejsze dzieje Uniejowa związane są z kasztelanią spycimierską, jedną z najstarszych w Polsce. Pierwsza pisemna wzmianka o mieście Uneievo, zamieszczona w bulli papieża Innocentego II, pochodzi z 1136 r. i dotyczyła zapisu o miejscowościach będących własnością biskupów gnieźnieńskich (rys. 1).

Liczba ludności zamieszkującej Uniejów zmieniała się na przestrzeni lat. 10 lat temu, czyli w 2004 r. liczba osób zameldowanych w nim na pobyt stały wynosiła 2960. 3 listopada 2014 r. w Uniejowie odnotowano 3002 osoby, w tym 1391 mężczyzn oraz 1611 kobiet.

Do najważniejszych walorów turystycznych w mieście zaliczyć można: dolinę Warty, rzekę Wartę, wody geotermalne, park przy Zamku Arcybiskupów Gnieźnieńskich, które należą do walorów przyrodniczych. Do walorów antropogenicznych zakwalifikowano: kolegiatę pw. Wniebowzięcia NMP, Zamek Arcybiskupów Gnieźnieńskich, kaplicę grobową rodziny Tollów, 
późnoklasycystyczny dworek szlachecki, średniowieczny układ przestrzenny miasta, Kompleks Termalno-Basenowy, Kompleks Boisk Piłkarskich im. W. Smolarka, Kasztel Rycerski Na Gorących Źródłach, Zagrodę Młynarską, a także liczne wydarzenia kulturalne m.in. Wielki Turniej Rycerski, Jarmark Średniowieczny, Wiosenne Pow-Wow Festiwal Muzyki Tańca Indian Ameryki Północnej, Indiańskie Lato, Święto Alei im. Sat-Okha, Dni Uniejowa, Ogólnopolskie Dni Wody, Festiwal „Królestwo Lilii”, Pożegnanie Wakacji oraz Jarmark Bożonarodzeniowy, Ogólnopolski Bieg do Gorących Źródeł „Sanus per aquam - zdrowie przez wodę".

Początki turystyki w Uniejowie można datować na lata międzywojenne. W tym czasie w Zamku Arcybiskupów Gnieźnieńskich funkcjonował pensjonat. Apartamenty dla gości znajdowały się w południowo-zachodnim skrzydle - najmniej zdewastowanej części obiektu (SALM 1995). Zamek stosunkowo krótko pełnił funkcje noclegowe. Po II wojnie światowej znajdował się tam magazyn nawozów sztucznych i zbóż.

Kolejne inwestycje związane $\mathrm{z}$ turystyką zostały poczynione $\mathrm{w}$ Uniejowie w latach 60. XX w. Powstały wówczas dwa obiekty: noclegowy „Zbyszko i Jagienka” oraz restauracja "Śródborze” zlokalizowane na terenie parku zamkowego (obecnie Uzdrowisko Uniejów Park). W 1992 r. zaczął funkcjonować prywatny obiekt noclegowo-gastronomiczny "Gościniec nad Wartą" znajdujący się przy drodze krajowej nr 72, który działa do chwili obecnej.

Lata 90. to powrót funkcji turystycznej do Zamku Arcybiskupów Gnieźnieńskich. Po pracach konserwatorskich w latach 1957-1967 przeprowadzonych według projektu Zdzisława i Heleny Ziętkiewiczów, obiekt pełnił funkcję archiwum, a następnie w 1995 r. przekazano go w zarządzanie Radzie Naczelnej Zrzeszenia Studentów Polskich (SALM 1995). Od tego czasu w zamku funkcjonował ośrodek konferencyjno-wypoczynkowy. W $2011 \mathrm{r}$. poddano go kolejnej rewitalizacji i od 2012 r. pełni ponownie funkcję noclegową będąc własnością PGK „Termy Uniejów”.

\section{Inwestycje turystyczne w Uniejowie w XXI wieku}

Najprężniej turystyka i związane z nią inwestycje turystyczne zaczęły rozwijać się od 2003 r. ${ }^{1}$ (rys. 1). Dzięki działaniom Samorządu Miasta i Gminy Uniejów w ciągu 11 lat zrealizowano inwestycje związane z turystyką o łącz-

\footnotetext{
${ }^{1}$ Funkcję burmistrza miasta Uniejów sprawuje od 2002 r. do chwili obecnej Józef Kaczmarek.
} 
nej wartości około 126,15 mln zł. Oprócz inwestycji turystycznych realizowanych przez władze gminy Uniejów przedsięwzięcia związane z turystyką podjęli prywatni przedsiębiorcy oraz spółki. Do większych prywatnych inwestycji należy zaliczyć budowę pensjonatu "Złoty Róg”, który funkcjonuje od 2009 r. Do Przedsiębiorstwa Gospodarki Komunalnej „Termy Uniejów” podlegającego Urzędowi Miasta Uniejów należą Kasztel Rycerski „Na Gorących Źródłach" otwarty w 2009 r., Kompleks Termalno-Basenowy otwarty w 2008 r., a rozbudowany w 2012., Zamek Arcybiskupów Gnieźnieńskich uruchomiony ponownie po renowacji w 2012 r., Zagroda Młynarska oraz Dom Pracy Twórczej funkcjonujące także od 2012 r.

Od 2012 r., czyli od rozbudowy Kompleksu Termalno-Basenowego, pojawiło się w mieście wiele nowych obiektów noclegowych, a także gastronomicznych (rys. 1). Przebudowy dawnego ośrodka wczasowego "Zbyszko i Jagienka" podjął się Instytut Zdrowia Człowieka z Warszawy. Od roku 2012 w wyremontowanych obiektach działa czterogwiazdkowy hotel Uzdrowisko Uniejów Park. Kolejny obiekt to hotel „Lawendowe Termy” żący do CS Investment Sp. z o.o. w Łodzi, uruchomiony również w 2012 r. Następną dużą inwestycją zrealizowaną przez prywatnego przedsiębiorcę jest hotel Uniejów ecoActive \& Spa****, który swoją działalność rozpoczął w 2013 r.

Oprócz dużych inwestycji nastawionych na pełnienie funkcji noclegowych powstało wiele kwater prywatnych i pokoi gościnnych. W Uniejowie znajduje się 20 takich obiektów, zlokalizowanych głównie na prawym brzegu Warty. Ich właścicielami są mieszkańcy Uniejowa (www.uniejow.pl).

Ważnymi obiektami zapewniającymi podstawowe potrzeby turystów są świadczące różnego rodzaju usługi gastronomiczne. W Uniejowie powstało ich 13 i są to: 11 restauracji, 3 bary, a także 3 pizzerie. Rozlokowano je w różnych częściach miasta, lecz przeważająca liczba obiektów znajduje się w centrum lub w jego sąsiedztwie. Kilka obiektów usytuowano na trasach wjazdowych do miasteczka, gdzie najczęściej zatrzymują się osoby przejeżdżające tranzytem.

Warto również wspomnieć o inwestycjach związanych z infrastrukturą towarzyszącą. W Uniejowie istnieją dwie firmy zajmujące się organizacją spływów kajakowych po Warcie - firma należąca do K. Ochockiego oraz firma VattenBall M. Łuczaka; ta druga zajmuje się jednak przede wszystkim organizacją imprez związanych z paintballem.

Według Słownika wospótczesnego języka polskiego (1998) termin „inwestycja” definiowany jest w dwóch kontekstach: „1. przeznaczenie środków finanso- 
wych na budowę i rozbudowę, modernizację obiektów majątku trwałego [...], 2. to co jest rezultatem przeznaczenia na coś pieniędzy, np. budynek, maszyna itp." Z kolei internetowy słownik - Wielki słownik języka polskiego (www.wsjp.pl) - przypisuje słowu „inwestycja” trzy znaczenia: 1. lokata przeznaczenie na coś pieniędzy w taki sposób, aby w przyszłości przyniosły zysk; 2. wytworzone dobra - to, na co przeznaczane są pieniądze i co ma przynieść w przyszłości zysk; 3. wkład w przyszłość - poświęcenie czasu i pieniędzy na coś, co stanowi punkt wyjścia do dalszego rozwoju i co przyniesie w przyszłości jakąś korzyść.

Przyjmując definicję inwestycji za Wielkim słownikiem języka polskiego inwestycję turystyczną określić można jako przeznaczenie środków pieniężnych, a także czasu, na dobra materialne odnoszące się do turystyki i służące jej uprawianiu, mające być punktem wyjścia do dalszego rozwoju i elementami przynoszącymi w przyszłości korzyści, zyski.

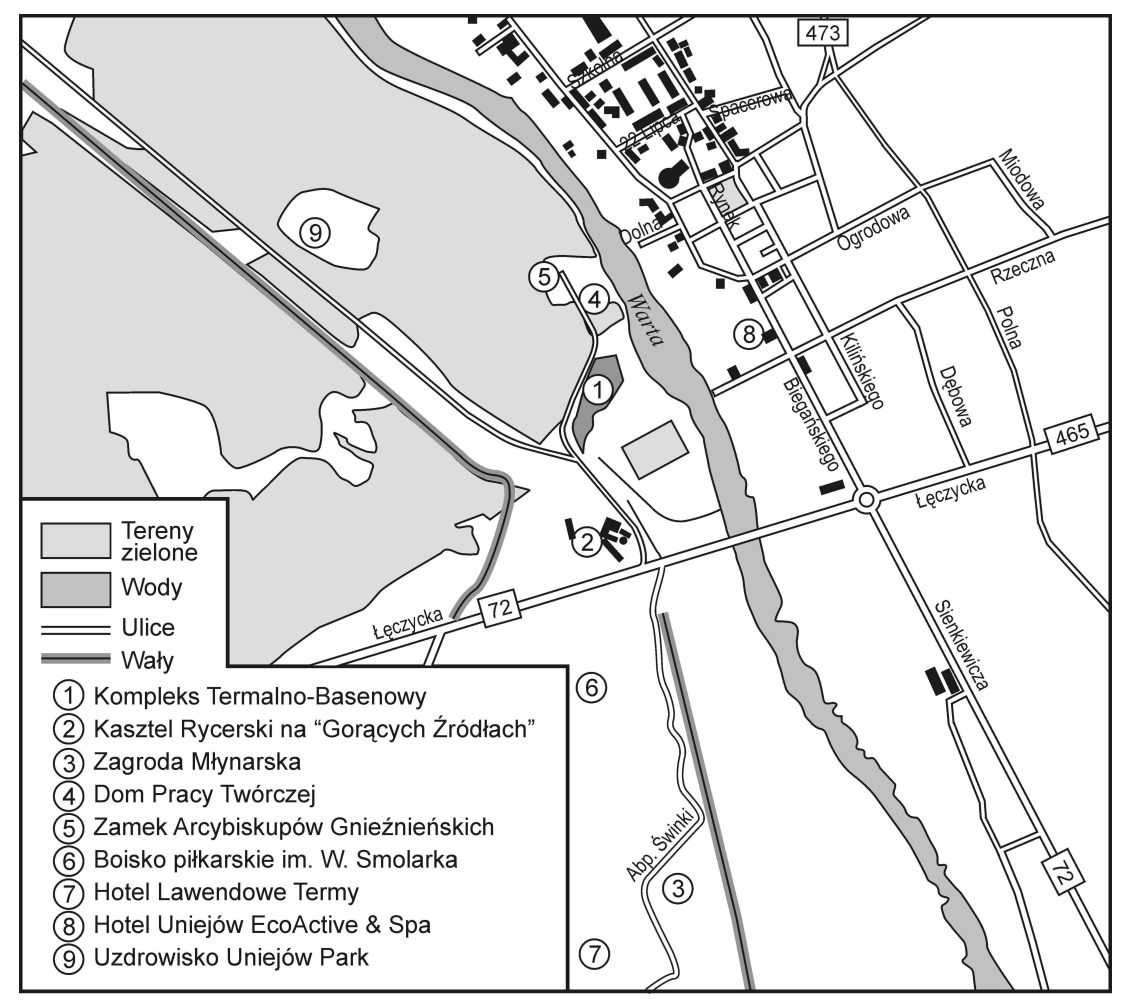

Rys. 2. Rozmieszczenie inwestycji turystycznych w Uniejowie w 2015 r.

Źródło: opracowanie własne 
Do najbardziej rozpoznawalnych inwestycji turystycznych w Uniejowie należą (rys. 2): Kompleks Termalno-Basenowy (1), Kasztel Rycerski „Na Gorących Źródłach” (2), Zagroda Młynarska (3), Dom Pracy Twórczej (DPT) (4), Zamek Arcybiskupów Gnieźnieńskich (5) , Kompleks Boisk Piłkarskich im. Włodzimierza Smolarka (6), hotel Lawendowe Termy (7), hotel Uniejów EcoActive \& Spa (8), Uzdrowisko Uniejów Park (9).

Większość środków finansowych przeznaczonych na realizację opisywanych tu inwestycji turystycznych w Uniejowie pochodziła z dotacji i grantów inwestycyjnych - głównie z funduszy unijnych. Na przedsięwzięcia związane $\mathrm{z}$ rozwojem turystyki najczęściej wykorzystywane są fundusze strukturalne oraz środki z Funduszu Spójności, a także z Funduszy Przedakcesyjnych oraz Sektorowych Programów Operacyjnych. Urząd Miasta Uniejów w ciągu dziewięciu lat zrealizował w sumie 16 projektów o wartości 283477 017,35 zł, w tym większość z nich dofinansowana została ze środków Unii europejskiej (tab. 1).

Tab. 1. Inwestycje w Uniejowie realizowane przez Urząd Miasta Uniejów

\begin{tabular}{|l|c|c|c|c|}
\hline $\begin{array}{c}\text { Okres } \\
\text { programo- } \\
\text { wania }\end{array}$ & $\begin{array}{c}\text { Liczba zrea- } \\
\text { lizowanych } \\
\text { projektów }\end{array}$ & $\begin{array}{c}\text { Całkowita } \\
\text { wartość } \\
\text { projektów (w zł) }\end{array}$ & $\begin{array}{c}\text { Dofinanso- } \\
\text { wanie } \\
\text { z UE (w zl) }\end{array}$ & $\begin{array}{c}\text { Suma } \\
\text { (w zł) }\end{array}$ \\
\hline $2004-2006$ & 7 & 25586095,59 & 13542170,98 & 39128266,57 \\
\hline $2007-2013$ & 9 & 134566903,94 & 109781846,84 & 244348750,78 \\
\hline Suma & $\mathbf{1 6 0 1 5 2 9 9 9 , 5 3}$ & $\mathbf{1 2 3 3 2 4} \mathbf{0 1 7 , 8 2}$ & $\mathbf{2 8 3 4 7 7 0 1 7 , 3 5}$ \\
\hline
\end{tabular}

Źródło: opracowanie własne na podstawie J. KACZMAREK (2014).

Realizowane inwestycje turystyczne przez Urząd Miasta Uniejów finansowano głównie ze środków Zintegrowanego Programu Operacyjnego Rozwoju Regionalnego oraz Regionalnego Programu Operacyjnego Województwa Łódzkiego na lata 2007-2013 (RPO WŁ).

\section{Jakość życia w wybranych koncepcjach teoretycznych}

"Jakość życia" to ważne pojęcie o subiektywnym wydźwięku oraz intuicyjnym postrzeganiu. Większość wysiłków, które podejmuje człowiek jest skierowanych na poprawę jakości życia jednostki i najbliższych jej osób. Człowiek oceniając jakość swojego życia przyjmuje zazwyczaj subiektywne kryteria, posługując się przy tym intuicyjnymi miernikami i sposobami po- 
miaru. Każdy pojmuje jakość życia inaczej i przyjmuje różne wartości, które jego zdaniem wpływają na poziom jakości życia.

Termin ,jakość życia” posiada wielorakie znaczenie - różne dyscypliny naukowe różnie ją definiują. R. KOLMAN (2002) określa jakość życia jako: sprawność funkcjonowania żywego organizmu, stopień zaspokojenia potrzeb życiowych człowieka (duchowych i materialnych), stopien spełnienia wymagań określających poziom materialnego oraz duchowego bytu jednostek i całego społeczeństwa. Pojęcie „jakość życia” wprowadzono do terminologii naukowej $\mathrm{w}$ latach 60 . XX w., ale powiązane $\mathrm{z}$ nim zagadnienia i problemy istniały od dawna. Problematyka jakości życia inaczej rozwijała się w psychologii, gdzie jej obszar zainteresowań ograniczał się do zagadnień związanych $\mathrm{z}$ tą dziedziną nauki, inaczej $\mathrm{w}$ medycynie, socjologii czy naukach ekonomicznych (WNUK, MARCINKOWSKI 2012).

B. KRYK I K. WŁODARCZYK-ŚPIEWAK (2006) szeregują występujące w literaturze układy dziedzin odnoszące się do jakości życia następująco:

1) dwie subagregatywne jakości życia typu „mieć" i „być”;

2) trzy dziedzinowe jakości życia - społeczną, ekonomiczną i środowiskową, z możliwością wydzielenia dziedziny instytucjonalnej;

3) siedem dziedzinowych jakości życia (według grup potrzeb) w metodzie genewskiej - wyżywienie, mieszkanie, zdrowie, wykształcenie, rekreacja, zabezpieczenie społeczne i zagospodarowanie materialne (wg DREWNOWSKIEGO, SCOTTA 1996);

4) dziewięć dziedzinowych jakości życia - dochody i wydatki ludności, zagrożenie ubóstwem i ubóstwo, warunki mieszkaniowe, bezrobocie, zdrowie i jego zagrożenie, edukacja, bezpieczeństwo, środowisko naturalne i styl życia;

5) trzynaście dziedzinowych jakości życia - małżeństwo i życie rodzinne, zdrowie, sąsiedztwo, przyjaciele i znajomi, życie w USA, miejsce zamieszkania, mieszkanie, praca zawodowa i domowa, czas wolny, wykształcenie i jego przydatność oraz bezpieczeństwo finansowe (wg CAMPBELLA 1976);

6) szesnaście dziedzinowych jakości życia według GUS - dzieci, życie osobiste, zdrowie, samopoczucie psychiczne, sąsiedzi, posiadanie przyjaciół, praca zawodowa, prowadzenie gospodarstwa domowego, miejsce zamieszkania, warunki mieszkaniowe, sposób spędzania wolnego czasu, ilość wolnego czasu, sytuacja materialna i realizacja zasad demokracji w kraju (wg MACIASZKA 1997); 
7) sześć dziedzinowych jakości życia - rodzinną, somatyczną, funkcjonalną, psychiczną, środowiskową i siedliskową (wg KOLMANA 2002).

Istnieje również podział na jakość życia subiektywną i obiektywną. Poziom życia, standard życia czy warunki życia przekładają się na obiektywny obraz jakości życia, a percepcja poziomu życia stanowi subiektywny poziom jakości życia.

Obiektywna jakość życia zbliżona jest do pojęcia warunków życia, które oznaczają całokształt obiektywnych warunków o charakterze infrastrukturalnym, w jakich żyje społeczeństwo (grupy społeczne, gospodarstwa domowe i jednostki) (SOMPOLSKA-RZECHUŁA 2013).

Do elementów obiektywnej jakości życia J. CZAPIŃSKI I T. PANEK (2013) zaliczają:

- sytuację dochodową gospodarstwa domowego i sposób gospodarowania dochodami;

- wyżywienie;

- zasobność materialną gospodarstwa domowego, w tym wyposażenie $\mathrm{w}$ nowoczesne technologie komunikacyjne (telefon komórkowy, komputer, dostęp do Internetu);

- warunki mieszkaniowe;

- pomoc społeczną, z jakiej korzysta gospodarstwo domowe;

- kształcenie dzieci;

- uczestnictwo w kulturze i wypoczynek;

- korzystanie z usług systemu ochrony zdrowia;

- sytuacje gospodarstwa domowego i jego członków na rynku pracy;

- ubóstwo, bezrobocie, niepełnosprawność i inne aspekty wykluczenia społecznego.

Subiektywna jakość życia natomiast to zestaw ocen obiektywnych faktów jakościowych (ocen stopnia zadowolenia z różnych obiektywnych form zaspokajania potrzeb człowieka) charakteryzujących różne aspekty życia człowieka i pochodzących ze skali psychologicznej (SOMPOLSKA-RZECHUŁA 2013).

Zagadnienia wchodzące $\mathrm{w}$ skład subiektywnej jakości życia są następujące (CZAPIŃSKI, PANEK 2013):

- ogólny dobrostan psychiczny (w tym wola życia, poczucie szczęścia, zadowolenie z życia, symptomy depresji psychicznej);

- zadowolenie z poszczególnych dziedzin i aspektów życia; 
- subiektywna ocena materialnego poziomu życia;

- różne rodzaje stresu życiowego (takie, jak stres administracyjny - kafkowski, związany z kontaktami z administracją publiczną, stres zdrowotny, stres rodzicielski, stres finansowy, stres pracy, stres ekologiczny, stres małżeński, stresowe wydarzenia losowe, jak napad, włamanie, aresztowanie);

- objawy somatyczne (miara dystresu, traktowana jako ogólna miara stanu zdrowia);

- strategie radzenia sobie ze stresem;

- korzystanie z systemu opieki zdrowotnej;

- finanse osobiste (m.in. dochody osobiste i zaufanie do instytucji finansowych);

- system wartości, styl życia oraz indywidualne zachowania i nawyki (np. palenie papierosów, nadużywanie alkoholu, używanie narkotyków, praktyki religijne);

- postawy i zachowania społeczne, w tym kapitał społeczny;

- wsparcie społeczne;

- zachowania i postawy obywatelskie;

- korzystanie z nowoczesnych technologii komunikacyjnych - komputera, Internetu, telefonu komórkowego;

- sytuację na rynku pracy i karierę zawodową;

- bezrobocie, niepełnosprawność i inne aspekty wykluczenia społecznego;

- powody niskiej dzietności Polaków.

Zastosowany przez R. KOLMANA (2002) podział jakości życia na sfery: psychiczną, funkcjonalną, somatyczną, środowiskową, siedliskową oraz rodzinną został przyjęty jako podstawa do ukazania wpływu inwestycji turystycznych na określone sfery jakości życia mieszkańców Uniejowa. $\mathrm{W}$ badaniach nie został uwzględniony aspekt rodzinny ze względu na niestwierdzenie powiązań między nim a działaniami inwestycyjnymi w mieście. Należy także podkreślić, że w sześciu wybranych do analiz sferach nie badano wszystkich, a jedynie możliwe do przebadania w konkretnych warunkach i przestrzeni aspekty, które zostały wyróżnione w tekście. 


\section{Jakość życia uniejowian w kontekście zrealizowanych inwestycji turystycznych}

Badania ankietowe przeprowadzono w roku 2014 (lipiec-grudzień) wśród mieszkańców Uniejowa i objęto nimi 206 osób. Udział w nich wzięły zarówno kobiety (107), jak i mężczyźni (99) w wieku powyżej 18 roku życia. W badaniach wykorzystano metodę kuli śnieżnej polegającą na dotarciu do nielicznej grupy respondentów, a następnie za ich pośrednictwem do kolejnych osób spełniających kryteria doboru. $Z$ tego powodu, pomimo dużego podobieństwa próby do populacji generalnej (wszyscy mieszkańcy) wyniki należy traktować jako sondażowe, poprzedzające kolejne badania pełne, oparte na doborze reprezentatywnym.

W badaniach w Uniejowie w kwestii jakości życia psychicznego skupiono się głównie na poczuciu zadowolenia z życia oraz bezpieczeństwa, a także na wpływie inwestycji turystycznych na tę sferę życia. Mieszkańców miasta zapytano: czy realizowane inwestycje turystyczne wpływają na poziom zadowolenia $\mathrm{z}$ życia?, oraz poproszono o uzasadnienie swojej odpowiedzi.

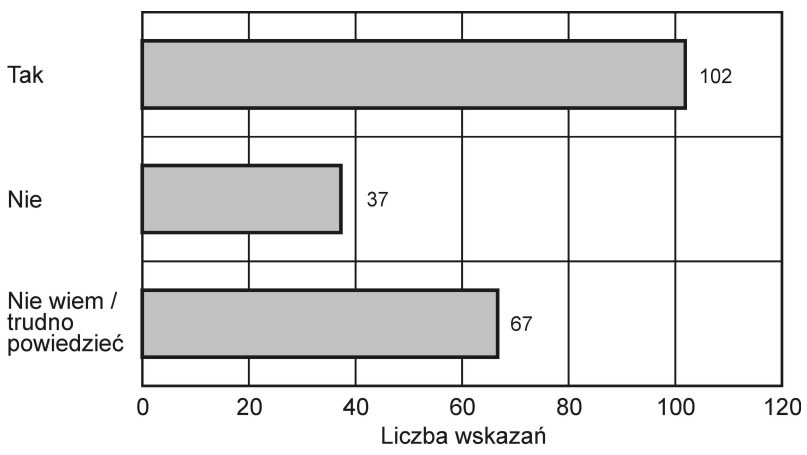

Rys. 3. Wpływ inwestycji turystycznych na poziom zadowolenia z życia ankietowanych mieszkańców Uniejowa

Źródło: opracowanie własne na podstawie badań ankietowych

Większość respondentów stwierdziło, że nowe inwestycje turystyczne mają wpływ na poziom zadowolenia $\mathrm{z}$ ich życia (rys. 3). 88 mieszkańców (na 102 odpowiedzi) uzasadniło swoją odpowiedź - najczęściej twierdząc, że dzięki tym inwestycjom istnieje wiele nowych możliwości spędzania wolnego czasu, wobec czego nie trzeba nigdzie wyjeżdżać, aby spędzić go za- 
dowalająco. Kolejnymi argumentami były: polepszenie ogólnego wizerunku miasta oraz jego rozwój, z czego są dumni, wzrost liczby nowych miejsc pracy, a także polepszenie zdrowia, dzięki np. powstałemu Kompleksowi Termalno-Basenowemu. Pojawiło się również kilka negatywnych odpowiedzi motywowanych napływem dużej liczby turystów oraz wyższymi cenami w punktach usługowych.

Prawie co piąty uniejowianin nie potwierdził wpływu inwestycji turystycznych na poziom zadowolenia ze swojego życia, argumentując tę opinię kilkoma powodami. Twierdzili m.in., że inwestycje nie mają związku z ich życiem, nic się dla nich nie zmieniło, bowiem rzadko korzystają z obiektów powstałych dzięki inwestycjom turystycznym w mieście. Dla 67 ankietowanych $(32 \%)$ trudne było określenie tego, czy poczynione inwestycje turystyczne wpłynęły w jakikolwiek sposób na ich zadowolenie z życia.

Poczucie bezpieczeństwa $z$ subiektywnego punktu widzenia ma istotne znaczenie dla jakości życia społeczności. Spadek poczucia bezpieczeństwa negatywnie wpływa na jakość życia psychicznego mieszkańców.

Na pytanie o wpływ inwestycji turystycznych na poczucie bezpieczeństwa ankietowani odpowiadali, że poczynione działania w mieście przyczyniają się do zmiany ich poczucia bezpieczeństwa (rys. 4).

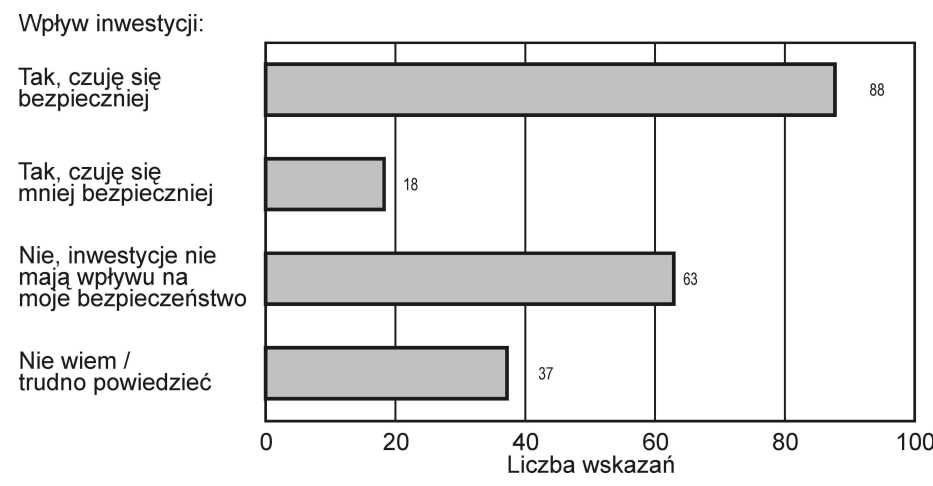

Rys. 4. Wpływ inwestycji turystycznych w Uniejowie na poczucie bezpieczeństwa respondentów

Źródło: opracowanie własne na podstawie badań ankietowych

Przeprowadzone badania wykazały, że $42 \%$ ankietowanych czuje się bezpieczniej dzięki inwestycjom turystycznym. Tylko około 9\% respondentów dostrzegło negatywny wpływ inwestycji turystycznych na poczucie ich bezpieczeństwa. Co trzeci ankietowany uniejowianin nie zauważył żadnych 
zmian w tej kwestii. Natomiast niemal 18\% badanych mieszkańców stwierdziło, że trudno wskazać jakikolwiek wpływ inwestycji na poczucie bezpieczeństwa.

Na życie funkcjonalne człowieka składa się zespół faktów i przemian jakościowych, które wpływają na przydatność społeczną jednostki. Należą do nich m.in.: zdobyta wiedza, kwalifikacje zawodowe, należyte wypełnianie obowiązków, posiadane umiejętności, osiągnięcia w działalności zawodowej i społecznej. Sferę tę można ogólnie określić działalnością człowieka na rzecz społeczeństwa (KOLMAN 2002).

Poczynione inwestycje turystyczne w Uniejowie wpłynęły korzystnie zdaniem respondentów - na poziom bezrobocia w mieście. Prawie $3 / 4$ ankietowanych zauważyło, że bezrobocie zmniejszyło się (rys. 5), tylko 11\% respondentów było zdania, że inwestycje te nie przyczyniły się do zmian w zakresie stopy bezrobocia w mieście. Relatywnie wysoko kształtowała się kategoria odpowiedzi „nie wiem/trudno powiedzieć”, z 17-procentowym udziałem w ogólnym wyniku. Nikt spośród ankietowanych mieszkańców nie dostrzegł jednak wzrostu bezrobocia w miejscu ich zamieszkania.

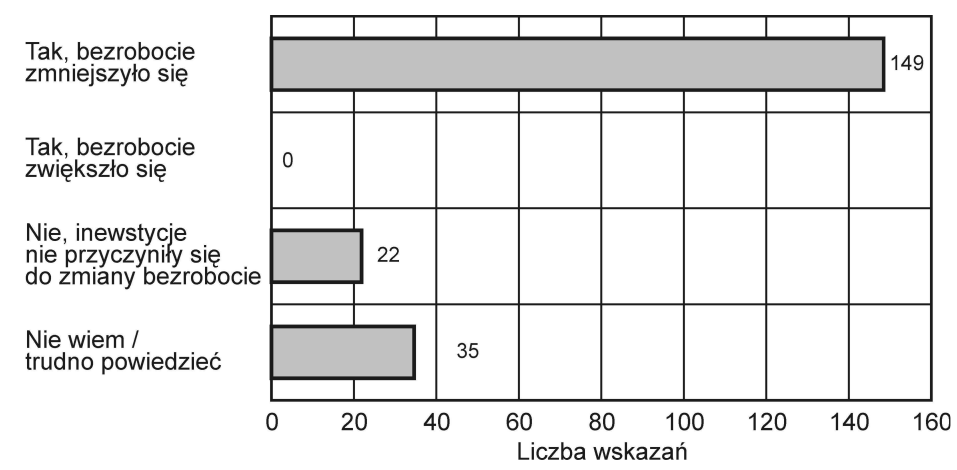

Rys. 5. Zmiany bezrobocia dzięki inwestycjom turystycznym w Uniejowie w opinii respondentów

Źródło: opracowanie własne na podstawie badań ankietowych

Kolejnym badanym zagadnieniem był wpływ inwestycji turystycznych na podnoszenie wykształcenia oraz zmiany kwalifikacji mieszkańców Uniejowa. W porównaniu zmian stopy bezrobocia, możliwości podnoszenia wykształcenia i zmian kwalifikacji oraz wpływu na te sfery inwestycji turystycznych widać wyraźne różnice. Niezbyt liczna grupa ankietowanych (15\%) zauważa bardzo duży bądź duży wpływ inwestycji na podnoszenie 
wykształcenia i zmiany kwalifikacji (rys. 6). Prawie 1/3 respondentów sądzi, że inwestycje mają średni wpływ na ten aspekt jakości życia funkcjonalnego. Zdaniem większości badanych uniejowian inwestycje turystyczne mają niewielki (mały bądź bardzo mały) wpływ na podnoszenie wykształcenia oraz zmiany kwalifikacji bądź nie oddziałują w ogóle na ten aspekt ich życia. Takiej odpowiedzi udzieliła ponad połowa respondentów.

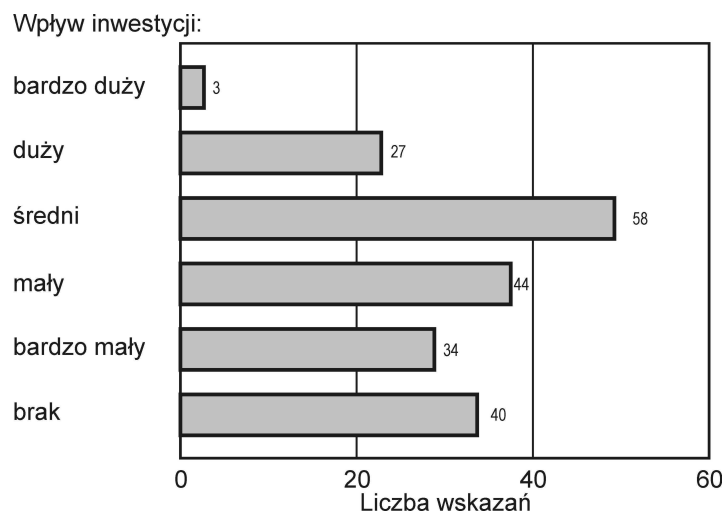

Rys. 6. Wpływ inwestycji turystycznych w Uniejowie na możliwości podnoszenia wykształcenia oraz zmiany kwalifikacji ankietowanych

Źródło: opracowanie własne na podstawie badań ankietowych

W dalszej części badań zapytano mieszkańców Uniejowa o wpływ inwestycji turystycznych na liczbe punktów usługowych w mieście. W opinii ankietowanych inwestycje turystyczne oddziałują na liczbę punktów usługowych - według $80 \% \mathrm{z}$ nich ich liczba wzrosła, natomiast zdaniem $1 \%$ zmalała (rys. 7). Tylko ośmioro uniejowian stwierdziło, że inwestycje turystyczne nie wpływają na liczbę i jakość punktów usługowych. Części respondentów (14\% ogółu badanych) trudno było określić, czy inwestycje turystyczne wywarły wpływ na rozwój punktów usługowych w mieście.

Ważną kwestią poruszoną w badaniach było oddziaływanie inwestycji turystycznych na ceny w punktach usługowych. Zdaniem większości ankietowanych inwestycje turystyczne negatywnie wpłynęły na ceny (rys. 8) przyczyniły się do wzrostu cen (66\%). Tylko 1\% respondentów było zdania, że inwestycje turystyczne wpłynęły na ich spadek. Co siódmy badany uniejowianin nie zauważył istotnych zależności między inwestycjami turystycznymi a cenami w punktach usługowych, natomiast dla 18\% trudno było określić stopień tych zależności. 


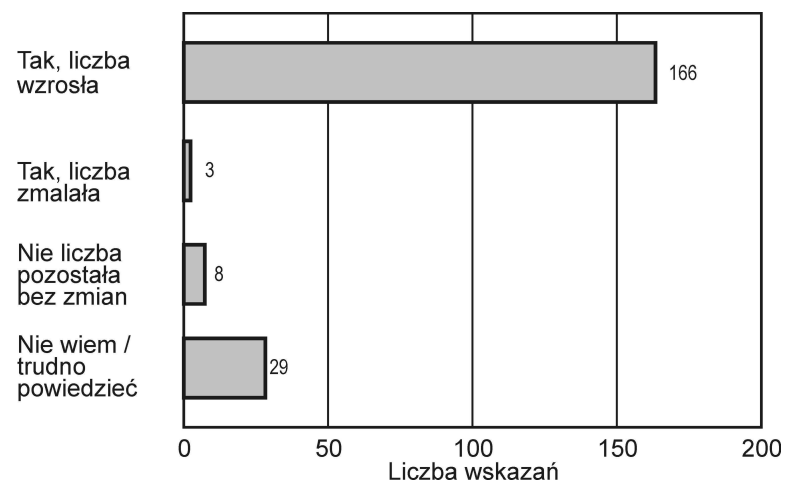

Rys. 7. Wpływ inwestycji turystycznych w Uniejowie na liczbę punktów usługowych w opinii respondentów Źródło: opracowanie własne na podstawie badań ankietowych

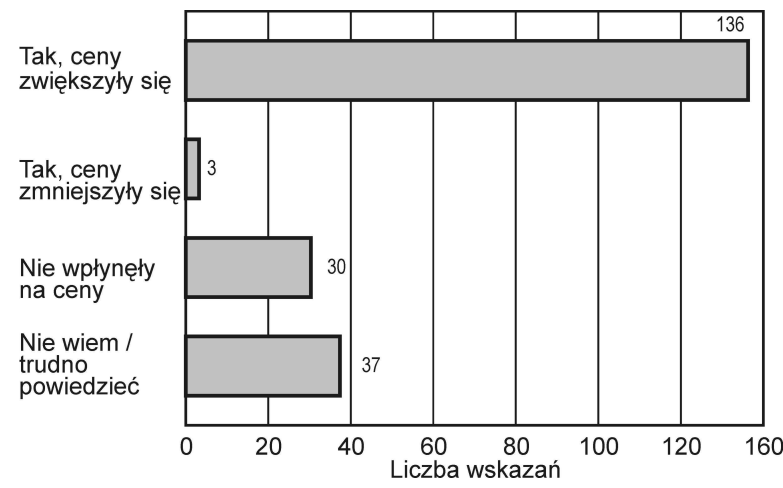

Rys. 8. Wpływ inwestycji turystycznych w Uniejowie na ceny $\mathrm{w}$ punktach usługowych $\mathrm{w}$ opinii respondentów

Źródło: opracowanie własne na podstawie badań ankietowych

Badana zbiorowość została poproszona o ocenę możliwości zaspokojenia wybranych potrzeb dzięki inwestycjom turystycznym $\mathrm{w}$ mieście. W większości przypadków oceny pozytywne dominowały nad negatywnymi. Do najlepiej zaspokajanych potrzeb dzięki inwestycjom turystycznym należały: kultura, turystyka, rekreacja i wypoczynek, sport, bezpieczeństwo publiczne, infrastruktura drogowa, dostęp do sklepów spożywczych, dostęp do firm usługowych oraz dostęp do infrastruktury teleinformatycznej. Najsłabiej dzięki inwestycjom turystycznym można było zaspokoić potrzebę rozwoju zawodowego. 
Średnie ważone oceny możliwości zaspokojenia potrzeb dzięki inwestycjom turystycznym w skali 1-5 wahają się od 2,51 - co oznacza, że są one słabe, do wartości 4,26 - określającej te możliwości jako dobre (rys. 9). Najwyżej w tym przypadku ocenione zostały potrzeby turystyki, rekreacji i wypoczynku, najniższą ocenę otrzymała potrzeba zaspokojenia rozwoju zawodowego. Na stosunkowo wysokim miejscu znalazł się dostęp do sklepów spożywczych, natomiast na drugim krańcu rankingu możliwość znalezienia pracy.

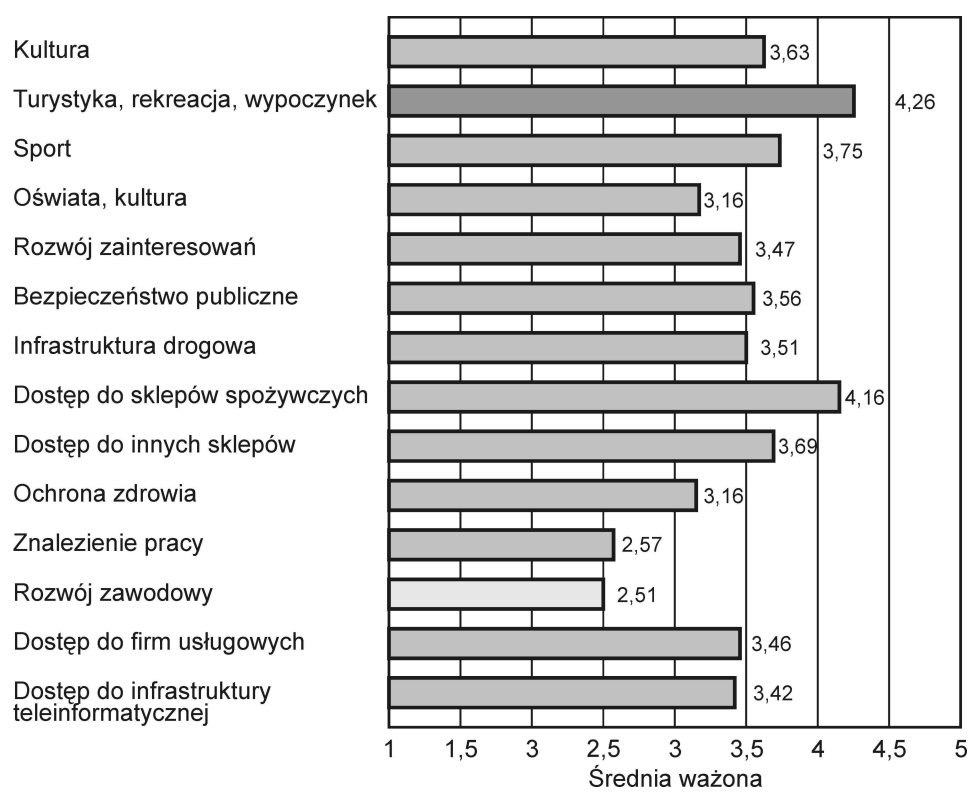

Rys. 9. Średnia ważona ocena możliwości zaspokojenia potrzeb mieszkańców dzięki inwestycjom turystycznym w Uniejowie Źródło: opracowanie własne na podstawie badań ankietowych

Z punktu widzenia jakości życia wymienione potrzeby mają duże znaczenie. Zaspokojenie potrzeb konsumpcyjnych, szczególnie żywnościowych, zgodnie $\mathrm{z}$ teorią A. Maslowa, należy do podstawowych potrzeb jednostki. Turystyka, rekreacja i wypoczynek zaliczane są natomiast do potrzeb wyższego rzędu i utożsamiane z wyższą jakością życia (MULARSKA-KUCHAREK 2014).

W kontekście jakości życia somatycznego ocenie poddane zostało zadowolenie respondentów ze zdrowia oraz wpływ na nie inwestycji turystycz- 
nych. Ankietowani zostali poproszeni również o wskazanie obiektów zagospodarowania rekreacyjnego na terenie Uniejowa oraz określenie częstotliwości korzystania z nich.

Na pytanie, czy inwestycje turystyczne wpływają na ich zdrowie? - tylko $24 \%$ respondentów odpowiedziało twierdząco (rys. 10). Uzasadniano to głównie poprawą kondycji fizycznej oraz samopoczucia, dzięki np. korzystaniu z leczniczych walorów Uniejowa, w tym z solankowych wód termalnych, oraz możliwości rehabilitacji. Zdaniem 34\% ankietowanych inwestycje turystyczne nie mają żadnego związku z ich stanem zdrowia, gdyż nie korzystają oni z walorów uzdrowiskowych, natomiast $42 \%$ badanych mieszkańców trudno było określić te relacje.

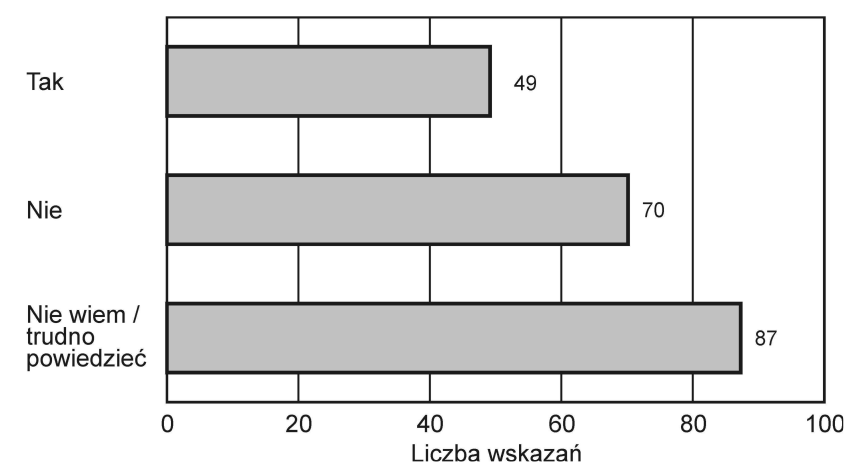

Rys. 10. Wpływ inwestycji turystycznych w Uniejowie na zdrowie respondentów Źródło: opracowanie własne na podstawie badań ankietowych

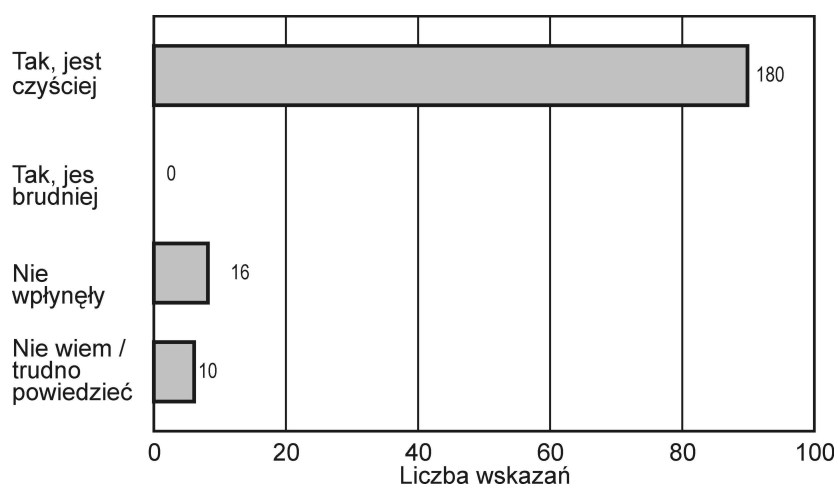

Rys. 11. Wpływ inwestycji turystycznych w Uniejowie na estetykę budynków, parków i skwerów oraz czystość i porządek w opinii respondentów

Źródło: opracowanie własne na podstawie badań ankietowych 
W opinii ankietowanych inwestycje turystyczne mają istotny wpływ na estetykę budynków, parków i skwerów oraz na czystość i porządek w Uniejowie. $87 \%$ respondentów było zdania, że dzięki inwestycjom turystycznym jest czyściej w mieście (rys. 11).

Około 8\% ankietowanych nie zauważyło w mieście żadnego wpływu inwestycji turystycznych na ten aspekt życia środowiskowego. Tylko 5\% badanych mieszkańców nie potrafiło określić zależności między tymi elementami, natomiast nikt nie dostrzegł negatywnego oddziaływania inwestycji turystycznych na tę sferę życia uniejowian.

Mieszkańców poproszono również o wskazanie elementów infrastruktury drogowej, na które największy wpływ mają inwestycje turystyczne. Ich zdaniem dzięki inwestycjom turystycznym powstało przede wszystkim więcej dróg i chodników, a już istniejące są w znacznie lepszym stanie dzięki ciągłej ich modernizacji (rys. 12). Zwiększyła się również liczba miejsc parkingowych oraz połączeń komunikacyjnych. Niewielka część respondentów zauważyła niekorzystny wpływ inwestycji turystycznych na elementy infrastruktury drogowej. W tym zakresie odnotowano 57 negatywnych wskazań na 742 udzielone odpowiedzi.

Więcej dróg
Mniej dróg
Drogi w lepszym stanie
Drogi w gorszym stanie
Więcej połączeń komunikacyjnych
Mniej połączeń komunikacyjnych
Większa liczba miejsc parkingowych
Mniejsza liczba miejsc parkingowych
Więcej chodników
Mniej chodników
Chodniki w lepszym stanie
Chodniki w gorszym stanie

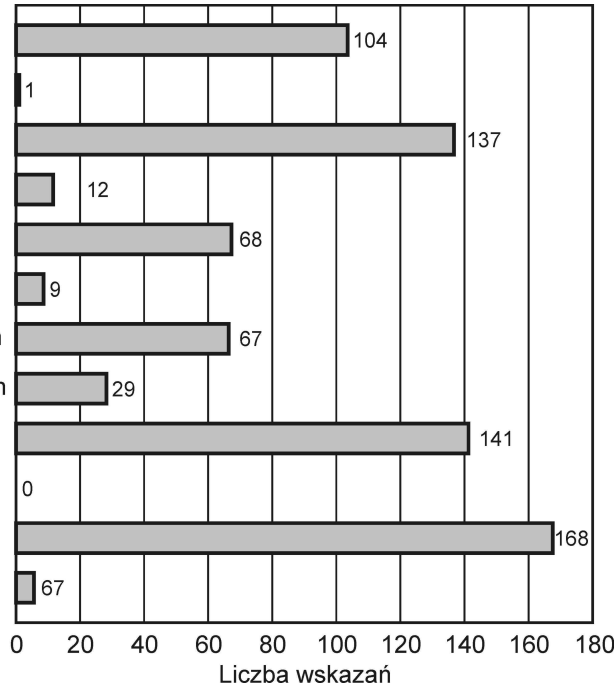

Rys. 12. Wpływ inwestycji turystycznych w Uniejowie na elementy infrastruktury drogowej w opinii respondentów

Źródło: opracowanie własne na podstawie badań ankietowych 
Kolejnym ważnym zagadnieniem było zbadanie wpływu inwestycji turystycznych na życie kulturalne mieszkańców Uniejowa. Część respondentów zauważyła ich wpływ (42\%), uzasadniając swoją odpowiedź głównie rozwojem kulturalnym poprzez udział $w$ organizowanych wydarzeniach, np. w koncertach czy festynach (rys. 13). Około $44 \%$ ankietowanym trudno było określić to, czy ten element oddziałuje na sferę ich życia kulturalnego. Zdaniem 14\% przebadanych uniejowian inwestycje turystyczne nie wpływają na ich życie kulturalne, ponieważ oferty kulturalne w mieście nie leżą w kręgu ich zainteresowań.

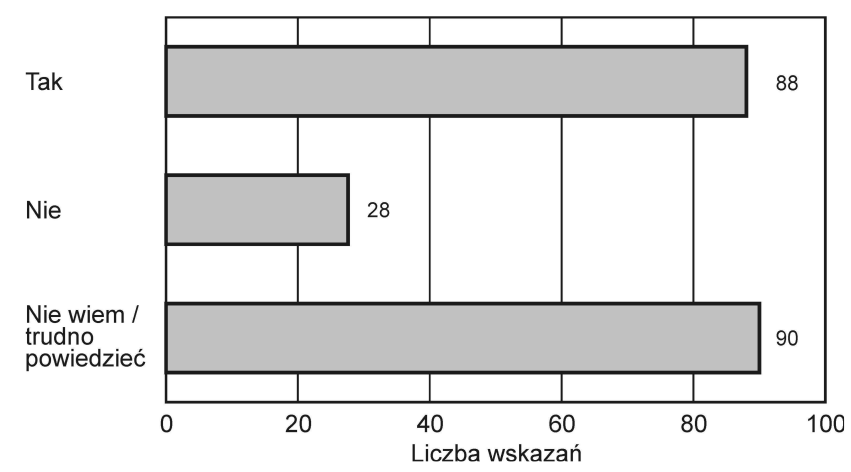

Rys. 13. Wplyw inwestycji turystycznych w Uniejowie na życie kulturalne respondentów

Źródło: opracowanie na podstawie badań ankietowanych

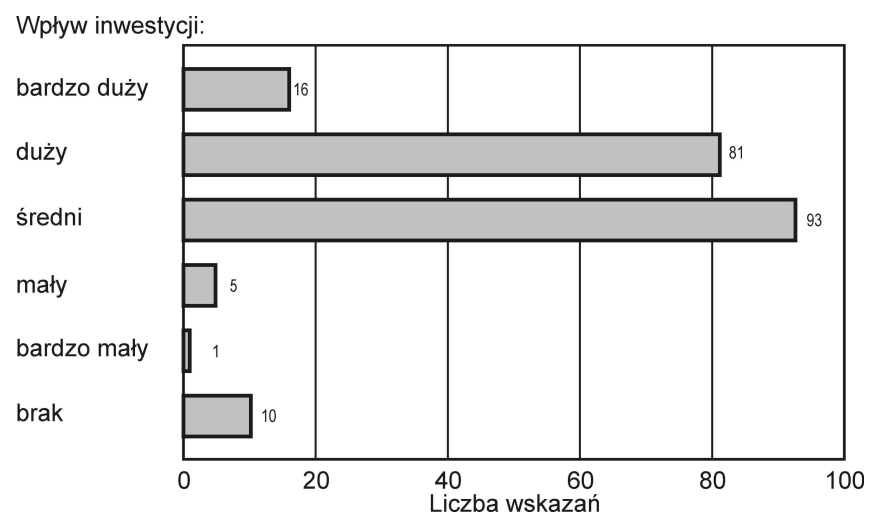

Rys. 14. Wpływ inwestycji turystycznych na integrację mieszkańców Uniejowa w opinii ankietowanych

Źródło: opracowanie na podstawie badań ankietowych 
Ważnym problemem sfery życia środowiskowego są relacje międzyludzkie. Ankietowanych zapytano o wpływ inwestycji turystycznych na integrację mieszkańców. Zdaniem $45 \%$ respondentów mają one średni wpływ na ten element życia środowiskowego (rys. 14). Około $40 \%$ badanych dostrzegło duże oddziaływania inwestycji turystycznych na integracje mieszkańców, a tylko $8 \%$ bardzo duże. W opinii 3\% relacje te są małe lub bardzo małe. Spośród 206 ankietowanych 10 osób nie zauważyło takich relacji w ogóle.

Kwestia wpływu inwestycji turystycznych na poziom zadowolenia uniejowian z miejsca zamieszkania w aspekcie jakości życia siedliskowego jest najważniejszym i najciekawszym aspektem badań. 37\% ankietowanych odpowiedziało, że inwestycje turystyczne w dużym stopniu wpłynęły na zadowolenie z miejsca zamieszkania (rys. 15).

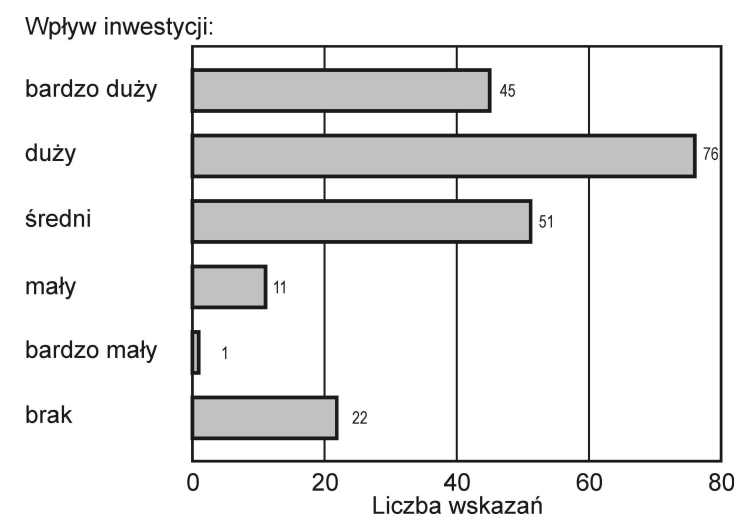

Rys. 15. Stopień wpływu inwestycji turystycznych w Uniejowie na zadowolenie z miejsca zamieszkania ankietowanych

Źródło: opracowanie własne na podstawie badań ankietowych

Prawie $60 \%$ respondentów zauważyło bardzo duży i duży wpływ inwestycji turystycznych na poziom zadowolenia $\mathrm{z}$ mieszkania $\mathrm{w}$ Uniejowie. Około $1 / 4$ ankietowanych stwierdziło, że poczynione działania $\mathrm{w}$ zakresie rozwoju turystyki w średnim stopniu przyczyniły się do poziomu ich zadowolenia z miejsca zamieszkania. Tylko 6\% badanych zauważyło mały lub bardzo mały wpływ inwestycji turystycznych na sferę ich życia siedliskowego. Co dziesiąty ankietowany nie dostrzegł żadnych zależności między zadowoleniem $\mathrm{z}$ miejsca zamieszkania a realizowanymi $\mathrm{w}$ mieście inwestycjami turystycznymi. 
Zdaniem większości respondentów (98\%) inwestycje turystyczne realizowane w Uniejowie mają duży wpływ na atrakcyjność turystyczną miasta (rys. 16). Dzięki nim ta atrakcyjność zwiększyła się w dużym stopniu (95\% odpowiedzi) lub w małym (3\%). Niespełna 9\% ankietowanych uważało, że wpływ inwestycji turystycznych na atrakcyjność turystyczną Uniejowa jest nieznaczny, w tym $2 \%$ respondentów sądzi nawet, że atrakcyjność turystyczna nieco się pogorszyła. Nikt spośród 206 badanych mieszkańców nie wskazał na duży negatywny wpływ inwestycji turystycznych na atrakcyjność miasta.

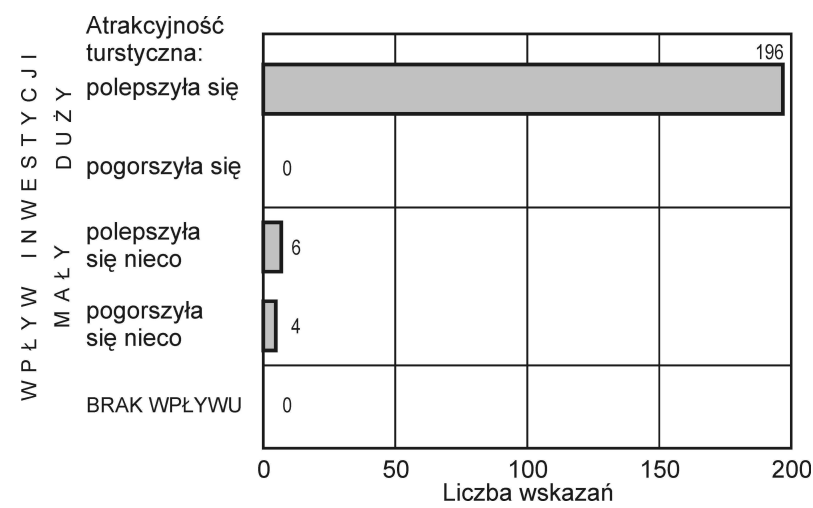

Rys. 16. Wpływ inwestycji turystycznych na atrakcyjność turystyczną Uniejowa

Źródło: opracowanie własne na podstawie badań ankietowych

Główną inwestycją turystyczną, która najbardziej przyczyniła się do zwiększenia atrakcyjności turystycznej jest zdaniem respondentów Kompleks Termalno-Basenowy (rys. 17). Spośród dziewięciu możliwych odpowiedzi tę wskazało $97 \%$ ankietowanych uniejowian.

Tylko cztery osoby (2\%) uważają, że Zamek Arcybiskupów Gnieźnieńskich jest inwestycją o największym znaczeniu dla atrakcyjności turystycznej miejscowości. Niecały 1\% ankietowanych wybrało Kompleks Boisk Piłkarskich jako najatrakcyjniejszą inwestycję turystyczną, natomiast $0,5 \%$ respondentów uważało, że jest nią Uzdrowisko Uniejów Park. Nikt z badanych nie wytypował Kasztelu Rycerskiego „Na Gorących Źródłach”, Zagrody Młynarskiej, Domu Pracy Twórczej, Lawendowych Term ani hotelu „Uniejów ecoActive \& Spa". 


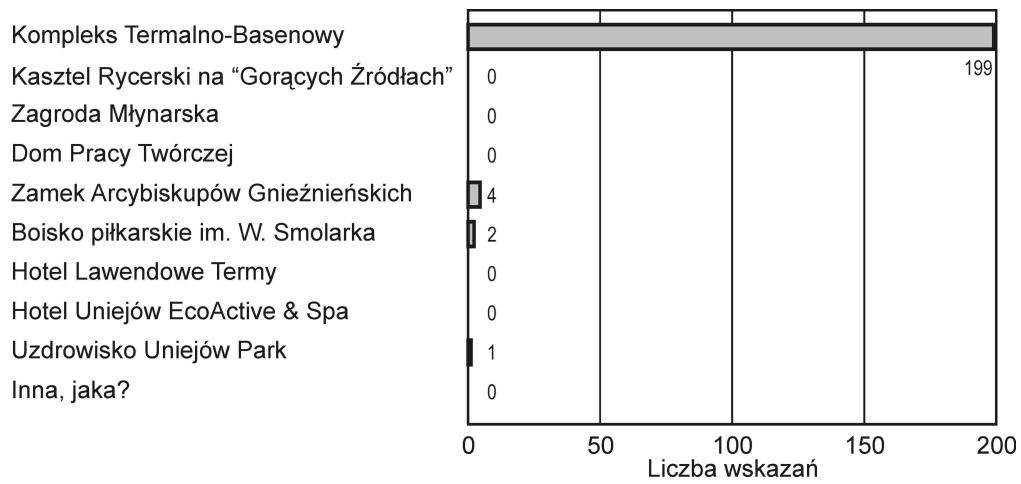

Rys. 17. Inwestycje turystyczne przyczyniające się do zwiększenia atrakcyjności turystycznej Uniejowa

Źródło: opracowanie własne na podstawie badań ankietowych

Takie wskazania spowodowane mogą być głównie faktem, że Kompleks Termalno-Basenowy cieszy się największą popularnością wśród obiektów najczęściej odwiedzanych przez turystów w Uniejowie i z każdym rokiem przyciąga ich coraz większą liczbę. Jest to inwestycja, której łączny koszt wyniósł 43,3 mln zł i były to największe poniesione nakłady finansowe spośród wszystkich inwestycji zrealizowanych w mieście.

Analizując ogólny wpływ inwestycji turystycznych na atrakcyjność turystyczną Uniejowa stwierdzić można, że jest on bardzo pozytywny. Respondenci w większości zauważają korzyści wynikające $\mathrm{z}$ poczynionych działań, wskazując przy tym Kompleks Termalno-Basenowy jako najważniejszą inwestycję przyczyniającą się do poprawy wizerunku miasta pod względem turystycznym.

\section{Podsumowanie}

Przeprowadzone w Uniejowie badania wśród jego mieszkańców na temat zależności między inwestycjami turystycznymi a jakością życia potwierdzają wyraźny pozytywny ich wpływ na poprawę jakości życia. Najwyraźniejsza zależność widoczna jest w życiu psychicznym i funkcjonalnym mieszkańców oraz w zakresie podniesienia atrakcyjności turystycznej miasta. Inwestycje turystyczne przyczyniają się do wyższego poziomu zadowolenia z życia oraz poczucia bezpieczeństwa, a także do zadowolenia z miejsca zamieszkania uniejowian. 
Dzięki tym inwestycjom zmniejszyło się bezrobocie w mieście (poprzez powstanie nowych miejsc pracy), zwiększyła się liczba punktów usługowych, choć jednocześnie wzrosły ceny produktów i usług w nich oferowanych. Powstałe inwestycje turystyczne według ankietowanych nie wpłynęły na podnoszenie poziomu wykształcenia oraz zmiany kwalifikacji zawodowych mieszkańców. Spowodowane może to być głównie brakiem szkoleń czy kursów prowadzonych w tym zakresie.

Respondentom trudno było określić wpływ inwestycji na ich zdrowie. Znaczna ich część nie korzystała z inwestycji turystycznych, w których istnieje możliwość regeneracji sił fizycznych i psychicznych, co jest wynikiem zbyt wysokich dla przeciętnego uniejowianina cen oferowanych usług.

Z badań wynika, że widoczny jest dla mieszkańców korzystny wpływ inwestycji turystycznych na estetykę budynków, parków i skwerów, a także, że dzięki tym inwestycjom - ich zdaniem - jest również czyściej w mieście. Władze Uniejowa podejmują działania mające na celu renowację i rewitalizację obiektów zabytkowych w celu podniesienia atrakcyjności turystycznej miasta. Poczynione w Uniejowie inwestycje turystyczne mają również wpływ na życie kulturalne mieszkańców. Biorą oni udział w wydarzeniach związanych z otwarciami nowych obiektów, a także przy okazji rocznic ich funkcjonowania. Ponadto uczestniczą $w$ imprezach organizowanych w powstałych obiektach. W średnim stopniu natomiast - zdaniem respondentów inwestycje wpływają na integrację mieszkańców. Powodem tego jest dość mała liczba organizacji, w których mieszkańcy mogliby udzielać się społecznie. Głównym powodem jest jednak niewiedza uniejowian na temat już powstałych formalnych i nieformalnych organizacji, brak czasu, ale także brak zainteresowania taką działalnością.

Istniejąca na terenie Uniejowa infrastruktura drogowa uległa znacznej poprawie. Powstały m.in. nowe drogi oraz chodniki, a te które istnieją, dzięki modernizacjom są w lepszym stanie. Zaspokojenie różnych potrzeb mieszkańców przez inwestycje turystyczne jest zróżnicowane. Turystyka, rekreacja i wypoczynek należą do najlepiej zaspokojonych potrzeb, czego główną przyczyną jest szeroka oferta miasta $\mathrm{w}$ tym zakresie, np. atrakcje turystyczne, zagospodarowanie rekreacyjne. Rozwój zawodowy należy natomiast do potrzeb zaspokojonych najsłabiej, co wynika z braku szkoleń czy kursów podnoszących kwalifikacje.

Mnogość inwestycji turystycznych zarówno dużych, jak i mniejszych przyczyniła się do zwiększenia atrakcyjności turystycznej miasta, a zdaniem respondentów powstały Kompleks Termalno-Basenowy wpłynął na nią naj- 
bardziej. Ankietowani zadowoleni są w większości z miejsca zamieszkania i wskazują na duże znaczenie nowych inwestycji turystycznych na takie ich poczucie, bowiem miasto stało się bardziej dla nich przyjazne.

Przeprowadzone badania dowiodły, że nowe inwestycje turystyczne w Uniejowie wpłynęły pozytywnie, choć w różnym zakresie zarówno na subiektywną, jak i obiektywną jakość życia jego mieszkańców.

\section{Bibliografia}

CZAPIŃSKI J., PANEK T. (red.), 2013, Diagnoza społeczna 2013, www.diagnoza.com; 11.05.2015.

DunAj B. (red.), 1998, Stownik wspótczesnego języka polskiego, t. 1, Reader's Digest Przegląd Sp. z o.o. Warszawa.

KACZMAREK J., 2014, Krajowa polityka miejska - spojrzenie Uniejowa, Uniejów.

КОВОJЕК Е. (red.), 2014, 2015, „,Biuletyn Uniejowski”, 3-4, Wyd. Uniwersytetu Łódzkiego, Łódź.

Kolman R., 2002, Jakość życia na co dzień, Oficyna Wydawnicza Ośrodka Postępu Organizacyjnego, Bydgoszcz.

KRYK B., WŁODARCZYK-ŚPIEWAK K., 2006, Wybrane aspekty jakości życia na przykładzie województwa zachodniopomorskiego, [w:] KOPYCIŃSKA D. (red.), Zachowania rynkowe gospodarstw domowych i przedsiębiorstw w okresie transformacji systemowej w Polsce, Katedra Mikroekonomii Uniwersytetu Szczecińskiego, Szczecin, s. 95-110.

MARSZAŁ T. (red.), 2012, 2013, „Biuletyn Uniejowski”, 1-2, Wyd. Uniwersytetu Łódzkiego, Łódź.

MULARSKA-KUCHAREK M., 2014, Wybrane aspekty jakości życia w opinii mieszkańców, „Biuletyn Uniejowski", 3, Wyd. Uniwersytetu Łódzkiego, Łódź, s. 53-66.

PRUGAR J., 2014, Mikrotoponimia i ojkonimia gminy Uniejów, „Biuletyn Uniejowski”, 3, Wyd. Uniwersytetu Łódzkiego, Łódź, s. 111-134.

SALM J., 1995, Zabytki Uniejowa. Urbanistyka i architektura, [w:] J. SZYMCZAK (red.), Dzieje Uniejowa, Wyd. Przyjaciół Uniejowa, Łódź-Uniejów, s. 423-452.

SAPIŃSKA-ŚLIWA A. 2012, Udostępnianie wód termalnych w Uniejowie - rys historyczny, , Biuletyn Uniejowski", 1, Wyd. Uniwersytetu Łódzkiego, Łódź, s. 63-77.

SMĘTKIEWICZ K., SMĘTKIEWICZ K., 2013, Przyrodnicze spacery po Uniejowie, Gmina Uniejów, Uniejów.

SOMPOLSKA-RZECHUŁA A., 2013, Jakość życia jako kategoria ekonomiczna, „Folia Pomeranae Universitatis Technologiae Stetinensis. Oeconomica", 71, s. 127-140.

SZYMCZAK J. (red.), 1995, Uniejów. Dzieje miasta, Towarzystwo Przyjaciół Uniejowa, Łódź-Uniejów.

WILUŚ R., 1997, Rozwój funkcji turystycznej w dolinie rzeki Warty na odcinku od Działoszyna do Uniejowa, Łódzkie Towarzystwo Naukowe, Łódź.

WNUK M., MARCINKOWSKI J.T., 2012, Jakość życia jako pojęcie pluralistyczne o charakterze interdyscyplinarnym, „Problemy Higieny i Epidemiologii”, 93(1), Poznań, s. 21-26.

www.uniejow.pl; 03.02.2015.

www.wsjp.pl; 23.03.2015.

www.rpo.lodzkie.pl; 08.05.2015.

www.uml.lodz.pl; 08.05.2015. 